\section{PP-577進行性腎細胞癌に対する分子標的薬逐次 投与の経験}

伊藤 英昭, 西嶋 淳, 宮近 義浩, 三角 拓, 長尾一公, 原 貴彦, 坂野 滋, 松山 豪泰

転移性腎細胞癌患者に sorafenib と sunitinib を逐次投与 し、1st line の投与で PD となった症例においても2nd line の投与で多くに一定の効果が認められたという報告が 散見される。我々は転移性腎細胞癌に対し sorafenibから sunitinib 逐次投与した 4 症例を経験したので、その効 果（交差耐性有無）と安全性について報告する。症例は男 性 2 例、女性 2 例。平均年齢 55.2 歳（32-71 歳）で、全て の症例に根治的腎摘除術が施行されていた。全例にリンパ 節転移もしくは他臟器転移を認め、3 例でサイトカイン療 法が施行されていた。Sunitinib 投与後の観察期間中央値 は、21 週（15-28 週）であった。Grade3 以上の有害事象は、 sorafenib では HFS、膵酵素上昇を 1 例で、sunitinib では Neutropenia 1 例で認めた。治療効果はいずれの症例も SDであった。これら 2 剂の交差耐性は低く、また毒性の 増強もないと考えられ、分子標的薬の逐次投与により転移 性腎細胞癌患者の生存を延長させる可能性が示唆された。 今後、RCT の結果が待たれる。

\section{山口大学大学院医学系研究科泌尿器科学分野}

\section{PP-579 Sequentaltherapy としてスニチニブを 使用した腎癌の臨床的検討}

\section{琉球大学医学部器官病態医科学講座泌尿器科学分野}

大城 吉則, 宮城 亮太, 喜友名 明日香, 玉城 光由, 田崎 新資, 松村 英理, 豊里 友常, 嘉手川 豪心, 安次嶺 聡, 町田 典子, 米納 浩幸, 斎藤 誠一 【緒言】本邦では転移性腎癌に対する分子標的薬として Sorafenibが最初に認可されたため、はじめにSorafenib が使われ、不応症例に対して Sunitinib が 2nd line で使 われる事が多いが、その sequetal therapy については一 定の見解はない。転移性腎癌で Sorafenib 不応となり、 2nd line で Sunitinibを使用した症例について検討した。 【対象】当院でSorafenib 不応となった転移性腎癌で、2nd line でSunitinib を使用した男性 5 例、女性 4 例。【結果】 平均年齢 $56.7 \pm 11.7$ 歳。腎摘出術有りが 8 例、無しが 1 例。組織型は clear cell type5 例、 papillary type 2 例、 spindle typel 例、不明 1 例で、転移部位は肺 6 例、肝 3 例、骨 3 例、副腎 2 例、腹壁 2 例、遠隔リンパ節 4 例、咽 頭 1 例（一部重複）であった。Sunitinibの前治療はサイ トカイン療法 + Sorafenib が 8 例、Sorafenib のみが 1 例。 Sorafenibの最大治療効果が PR/SD 4 例は、2nd line の Sunitinib ではPR 1 例、SD 3 例であったが、Sorafenibで の最大治療効果が PD 5 例は Sunitinibでも PD であった。 【考案】Sorafenib 有効例は不応状態になっても、2nd line の Sunitinibでも治療効果を認め、Sorafenib で無効例では Sunitinibでも無効であった。Sorafenib は Sunitinibより重 篤な副作用が少ないことより、 sequetal therapy では 1st line で Sorafenib、2nd lineでSunitinib が良いと考える。

\section{PP-580 ソラフェニブが原因と考えられた急性膵 炎の一例}

\section{刈谷豊田総合病院泌尿器科}

北里大学医学部泌尿器科学

藤田 哲夫, 岩村 正嗣, 池田 勝臣, 笹本 治子, 田畑 健一, 松本 和将, 吉田一成, 馬場 志郎

【目的】進行性腎細胞癌に対して 2 種類の分子標的薬が使 用可能になり，症例の集積と共に各種治療効果や副作用が 報告されている。今回我々は, 進行性腎細胞癌に対しソラ フェニブ・スニチニブ交替療法を行った症例を検討したの で報告する。

【力法】転移巣を有する進行性腎細胞癌に対し，ソラフェ ニブを投与した後にスニチニブを投与した 6 例を対象とし た。男性 3 例，女性 3 例で，交替療法時の平均年齢は 60.7 歳 $(52 \sim 67$ 歳) であった。交替療法の経緯及び治療効果 について検討した

【成績】 6 例中 4 例は, ソラフェニブの投与によって薬疹 を生じアレルギーテスト陽性となったため, ソラフェニブ の継続投与が不可能となり，スニチニブに交替した，2例 は, ソラフェニブ投与後の治療効果がPD となったため, スニチニブに交替した．交替療法を行った 6 例中全例でス ニチニブの継続投与が可能であった．交替療法後のスニチ ニブの治療効果はPRが4例, SDが1例, PDが1例であった. 【結論】ソラフェニブによって薬疹を生じた症例でもスニ チニブは継続投与が可能であり，さらに治療効果を認める ことが証明された。今回の検討は，有害事象や治療効果の 面でソラフェニブの投与が不可能になった症例に対するス ニチニブの投与症例であったが, 今後さらにこれら 2 剤の 選択方法の検討が必要であると考えられた。
犬塚 善博, 平林 崇樹, 近藤 厚哉, 伊藤 裕一,

田中 國晃

今回われわれは、ソラフェニブが原因と考えられた急性 膵炎の一例を経験したので報告する。症例は 69 歳男性。 2004 年 7 月 2 日に経胸腹的右腎摘除術を施行。Renal cell carcinoma G3 INF $\beta$ pT3aNOM1 (肺転移)であった。術 後 IFN $a$ を開始するも、うつ状態となり中止した。2004 年 10 月 27 日に肺転移切除術を施行した。その後、肺転移 再発し、2008年 8 月 18 日 肺区域切除した。同年 12 月 26 日、CTにて両側肺転移再々発を確認した。2009 年 1 月 6 日辛开バール内服を開始した $(800 \mathrm{mg} /$ 日) ところ、 10 日で薬疹を生じ中止した。6 週後から $200 \mathrm{mg} /$ 日で、再 開。6月はじめからは 400mg/日に増量したが、その 1 週 間後に嘔吐・腹痛を生じ来院、血清アミラーゼの異常高值、 腹部 CT 所見から重症膵炎と診断した。蛋白凝固阻害剂、 抗生剤の動注療法、CHDF を施行、ICUでの管理を行い 救命することができた。 